\title{
ANTIMICROBIAL ACTIVITY OF AQUEOUS EXTRACTS OF POTENTILLA REPTANS L. RHIZOME AND AERIAL PART
}

Marina Tomovic ${ }^{1}$, Marija Popovic-Milenkovic ${ }^{2}$, Slobodan Jankovic ${ }^{3}$

${ }^{1}$ Department of Pharmacy, Faculty of Medical Sciences, University of Kragujevac, Kragujevac, Serbia ${ }^{2}$ Community Pharmacy of Kragujevac, Kragujevac, Serbia

${ }^{3}$ Department of Pharmacology, Faculty of Medical Sciences, University of Kragujevac, Kragujevac, Serbia

\author{
ANTIMIKROBNA AKTIVNOST VODENIH EIKSTRAKATA NADZEMNOG \\ DELA I RIZOMA POTENTILLA REPTANS L. \\ Marina Tomović1, Marija Popović-Milenković ${ }^{2}$ Slobodan Janković ${ }^{3}$ \\ ${ }^{1}$ Department of Pharmacy, Faculty of Medical Sciences, University of Kragujevac, Kragujevac, Serbia \\ ${ }^{2}$ Apotekarska ustanova Kragujevac, Kragujevac, Srbija \\ ${ }^{3}$ Katedra za farmakologiju, Fakultet medicinskih nauka, Univerzitet u Kragujevcu, Kragujevac, Srbija
}

Received / Primljen: 28. 04. 2017.

Accepted / Prihvaćen: 07. 08. 2017.

\section{ABSTRACT}

Potentilla reptans is a little studied plant of the genus Potentilla, the family Rosaceae. The aim of this study is to determine antimicrobial effects of aqueous extracts of P. reptans aerial part and rhizome against standardized bacterial strains.

The antimicrobial activity of aqueous extracts of $P$. reptans aerial part and rhizome was tested against one fungus, Candida albicans, and two standard bacterial strains, Staphylococcus aureus and Escherichia coli, using an agar diffusion method.

Both examined extracts showed a significant antimicrobial activity against Escherichia coli and Staphylococcus aureus at the concentrations of 10 to $150 \mathrm{mg} / \mathrm{ml}$. The rhizome extract showed stronger antimicrobial effect against the tested strains of bacteria than the aerial part extract.

The obtained results represent preliminary results of antimicrobial activity of this plant and suggest that in future, the studies should examine antimicrobial activity against other bacterial strains and minimum inhibitory concentration.

Keywords: Potentilla reptans; Antimicrobial effect; Agar diffusion method.

\section{SAŽETAK}

Potentilla reptans je malo istraživana biljka roda Potentilla familije Rosaceae. Ciljove studije je utvrdivanje antimikrobnih efekata vodenih ekstrakata herbe i rizoma P. reptans na standardizovanim bakterijskim sojevima.

Antimikrobna aktivnost vodenih ekstrakata herbe $i$ rizoma Potentilla reptans je ispitivana na jednu gljivicu Candida albicans i dva standardna bakterijska soja Staphylococcus aureus $i$ Escherichia coli korišćenjem agar-difuzione metode.

Oba ispitivana ekstrakta su pokazala da u koncentracijama od 10 - $150 \mathrm{mg} / \mathrm{ml}$ ispoljavaju značajnu antimikrobnu aktivnost prema Escherichia coli $i$ Staphylococcus aureus. Ekstrakt rizoma je pokazao jači antimikrobni efekat nego herba kod oba ispitivana bakterijska soja.

Dobijeni rezultati predstavljaju preliminarne rezultate o antimikrobnom delovanju ove biljke $i$ ukazuju da buduća istraživanja mogu da idu u smeru ispitivanja antimikrobnog delovanja na drugim bakterijskim sojevima, kao i utvrduvanje minimalne inhibitorne koncentracije.

Ključne reči: Potentilla reptans; Antimikrobno delovanje; agar difuziona metoda.

\section{2}

\section{ABBREVIATIONS}

P.rep-a - Potentilla reptans aerial part

P.rep-r - Potentilla reptans rhizome

\section{INTRODUCTION}

Potentilla reptans L. (P. reptans) is one of three hundred Potentilla species belonging to the genus Potentilla, the family Rosaceae. The genus Potentilla is mostly characterized by perennial, rarely biennial or annual herbaceous plants (1). P. reptans is a perennial herbaceous plant with an erect rhizome. The stem is herbaceous, thread-like, creeping, up to $100 \mathrm{~cm}$ long, and the leaves are palmately five or seven lobed. It is usually found near the shores, in wet and flood meadows (2). The rhizome and aerial part of this plant are used in traditional medicine in the treatment of rheumatism, scabies, diarrhea, viral infections and as a remedy for wound-healing detoxification or internally 
in jaundice and dysentery (1). Studies that have examined the pharmacological characteristics of $P$. reptans aerial part proved its antioxidant and anti-ulcer activities $(3,4)$. Anti-inflammatory effect of the rhizome and aerial part was evaluated and proven by experimental mouse ear edema model (5). The results proved the presence of following compounds (Chinic acid, Caffeic acid, Protocatechuic acid, Luteolin-7-O-glucoside, Quercetin-3-O-glucoside, Rutin, Quercetin, Kaempferol-3-O-glucoside, Apigenin-7-O-glucoside) in the aerial part of $P$. reptans $L$. and Catechin as a dominant compound in the rhizome of this plant, as well as the presence of Chinic acid, Gallic acid, Protocatechuic acid, Epicatechin, Quercetin (5).

A large number of Potentilla species showed moderate to high antimicrobial activity. Antimicrobial activity was demonstrated against Streptococcus mutans and Streptococcus sobrinus, while moderate antibacterial activity was observed against Staphylococcus aureus and Bacillus substilis, and there is no such activity or it is very weak against Escherichia coli, Pseudomonas aeruginosa and Klebsiella pneumonia (1). A study showed antimicrobial activity of $P$. reptans aerial part and rhizome against gram-positive Staphylococcus aureus and Bacillus subtilis and gram-negative Escherichia coli and Pseudomonas aeruginosa bacterial strains (6).

The aim of our study is to justify the use of this plant as antimicrobial agent in traditional medicine.

\section{METHODS}

\section{Plant material}

The aerial parts of $P$. reptans were collected from May to August 2010, and rhizome in October of the same year. Plant material was dried for two weeks (in a windy, shady place). Before preparation of the extract, the material was kept at the temperature of $6-8^{\circ} \mathrm{C}$. Immediately prior to extraction, the plant material was powdered. The voucher specimens were deposited in herbarium of botanical garden of Department of Biology, Faculty of Natural Sciences, University of Belgrade, Serbia, no. BEOU 16405.

\section{Preparation of dry extracts}

Aerial part and rhizome extracts were obtained by the infusion method (7). For extraction, $20 \mathrm{~g}$ of dried and powdered aerial part (P.rep-a), and rhizome (P.rep-r) and 200 $\mathrm{ml}$ of boiling distilled water were used. The resultant extract was filtered and evaporated using a rotary vacuum evaporator at $40^{\circ} \mathrm{C}$, (RV05 basic IKA, Germany).

\section{Testing of antimicrobial activity}

In order to determine possible antimicrobial activity, P.rep- $a$ and P.rep- $r$ aqueous extracts were tested in vitro against one fungus and two standard ATCC bacterial strains using the agar diffusion method (8). Standard bacterial strains used in the test were: Staphylococcus aureus ATCC 25923 and Escherichia coli ATCC 25922, as well as the fungus Candida albicans ATCC 10231.
The testing started at concentrations ranging from 10 $\mu \mathrm{g} / \mathrm{ml}$ to $10 \mathrm{mg} / \mathrm{ml}$, wherein the positive results were observed at concentrations above $10 \mathrm{mg} / \mathrm{ml}$. The experiment was further carried out at concentrations: 10, 50, 75, 100 and $150 \mathrm{mg} / \mathrm{ml}$ which were obtained by diluting the appropriate amount of extract in distilled water.

Müeller Hinton agar medium was used for testing the sensitivity of bacteria to the obtained extracts (HiMedia Laboratories, India, LOT 0000099844), and Sabouraud agar plate was used for the fungus Candida albicans (Institute of Immunology and Virology "Torlak", Belgrade).

The concentration of bacterial broth was diluted $\left(10^{2}\right.$ organisms $/ \mathrm{ml}$ ) and volume of $0,1 \mathrm{ml}$ of each broth was applied to the surface of the agar plate. Then the appropriate strain substrate was poured into sterile $90 \mathrm{~mm}$ diameter petri dishes, so that the thickness of the solidified agar was $4 \mathrm{~mm}$. The reservoirs of diameter $12 \mathrm{~mm}$ were made in agar and in each well was introduced appropriate concentration of extracts in volume - of $150 \mu \mathrm{l}$.

Thus prepared agar plates were incubated at $37^{\circ} \mathrm{C}$ during before $24 \mathrm{~h}$. Inhibition zone diameters of plant extracts and standard substances were determined. Inhibition zones were determined by measuring the diameters in millimeters (12 $\mathrm{mm}$ diameter of the reservoir was subtracted from the displayed values of the inhibition zone diameter), and in cases when the inhibition zone diameter was smaller or equal to 12 $\mathrm{mm}$, the tested sample was considered to be inactive (8).

\section{Statistics}

Statistical analysis was performed using SPSS software. Inhibition zone values for each disk were shown in a scatter diagram, and linear regression lines were calculated using the least squares method. Diffusion zone values for each concentration of the extracts were plotted on scatter diagrams, and regression lines were calculated by the least squares method. The significance of the difference in the activity of the extracts against selected microorganisms was calculated using Mann - Whitney test $(\mathrm{p}<0,05)$.

\section{RESULTS}

Agar diffusion test results showed that the aqueous extracts of $P$. reptans aerial parts and rhizome at the concentrations of $10-150 \mathrm{mg} / \mathrm{ml}$ had significant antimicrobial activity against Escherichia coli and Staphylococcus aureus. Maximum antimicrobial activity was displayed at the highest concentrations applied. Aerial part extract at the concentration of $150 \mathrm{mg} / \mathrm{ml}$ showed $95,24 \%$ of ceftriaxone activity (30 $\mu \mathrm{g} /$ disk) against Escherichia coli, and 68,75\% against Staphylococcus aureus. Rhizome extract at the concentration of $150 \mathrm{mg} / \mathrm{ml}$ showed $133,3 \%$ activity of the standard against Escherichia coli, and $87,5 \%$ of ceftriaxone activity $(30 \mu \mathrm{g} /$ disk) against Staphylococcus aureus. The strain of Candida albicans showed moderate sensitivity to P.reptans rhizome and the highest applied concentration exhibited $50 \%$ activity in comparison to that of the refer- 
ence substance - nystatin $(25 \mu \mathrm{g} /$ disk $)$. The results of antimicrobial activity are shown in Table 1.

The mean value of the diameter of inhibition zones P.rep-r versus Staphylococcus aureus was $25.2 \pm 1.16 \mathrm{~mm}$ for P.rep-a $15.2 \pm 3.93 \mathrm{~mm}$. While the mean value of the diameter of inhibition zones P.rep-r versus Escherichia coli was $23.4 \pm 1.5 \mathrm{~mm}$ and for a P.rep-a $17.2 \pm 0.86 \mathrm{~mm}$. The differences in antimicrobial activity of the extracts against respective bacteria are displayed in Figures 1 and 2 .

\section{DISCUSSION}

Many of the plants used in traditional medicine were studied in order to prove their antimicrobial activity and justify their use in the treatment of various diseases caused by variety of microorganisms. Antimicrobial activity of $P$. reptans rhizome and aerial parts in this study was tested on standardized strains of microorganisms. The extacts of solvents such as ethanol, methanol, acetone, chloroform etc, are richer in active compounds than aqueous solvents and this greatly influences the appearance of antimicrobial effects (9). The tested aqueous extracts were obtained in a manner that is most commonly used in traditional medicine.

The $75 \%$ ethanol extract of $P$. reptans rhizome at concentration of $8 \mu \mathrm{g} / \mathrm{mL}$ showed significant antimicrobial effect against S. aureus, as well as the $25 \%$ ethanol extract of the rhizome at concentration of $40 \mu \mathrm{g} / \mathrm{mL}$. The $25 \%$ ethanol extract of $P$. reptans leaves showed antimicrobial activity against $B$. subtilis at concentration of $40 \mu \mathrm{g} / \mathrm{mL}$. Decoctions and $25 \%$ ethanol extracts of $P$. reptans root showed the activity against $E$. coli at the concentration of $200 \mu \mathrm{g} /$ $\mathrm{mL}$ (6). Our study results were in accordance with the results that had been shown before but the concentration of our extracts $(10 \mu \mathrm{g} / \mathrm{mL})$ did not show any effect. However, at higher concentrations $P$. reptans aerial part and rhizome showed a significant antimicrobial activity. This difference

Table 1. Antimicrobial activity of aqueous extracts of $P$. reptans rhizome and aerial parts

\begin{tabular}{|c|c|c|c|c|}
\hline \multicolumn{5}{|c|}{ Diameter of inhibition zones (mm) } \\
\hline \multicolumn{2}{|c|}{ Material } & $\begin{array}{c}\text { Escherichia } \\
\text { coli }\end{array}$ & $\begin{array}{c}\text { Staphylococ- } \\
\text { cus aureus }\end{array}$ & $\begin{array}{l}\text { Candida } \\
\text { albicans }\end{array}$ \\
\hline \multirow[t]{5}{*}{ P.rep-a } & $10 \mathrm{mg} / \mathrm{ml}$ & 15 & 0 & 0 \\
\hline & $50 \mathrm{mg} / \mathrm{ml}$ & 16 & 16 & 0 \\
\hline & $75 \mathrm{mg} / \mathrm{ml}$ & 17 & 18 & 0 \\
\hline & $100 \mathrm{mg} / \mathrm{ml}$ & 18 & 20 & 0 \\
\hline & $150 \mathrm{mg} / \mathrm{ml}$ & 20 & 22 & 0 \\
\hline \multirow[t]{5}{*}{ P.rep-r } & $10 \mathrm{mg} / \mathrm{ml}$ & 19 & 22 & 0 \\
\hline & $50 \mathrm{mg} / \mathrm{ml}$ & 22 & 23 & 0 \\
\hline & $75 \mathrm{mg} / \mathrm{ml}$ & 23 & 26 & 0 \\
\hline & $100 \mathrm{mg} / \mathrm{ml}$ & 25 & 27 & 16 \\
\hline & $150 \mathrm{mg} / \mathrm{ml}$ & 28 & 28 & 17 \\
\hline \multicolumn{2}{|c|}{ Ceftriaxone $30 \mu \mathrm{g} /$ disk } & 21 & 32 & - \\
\hline \multicolumn{2}{|c|}{ Nystatin 100 IJ/disk } & - & - & 34 \\
\hline
\end{tabular}

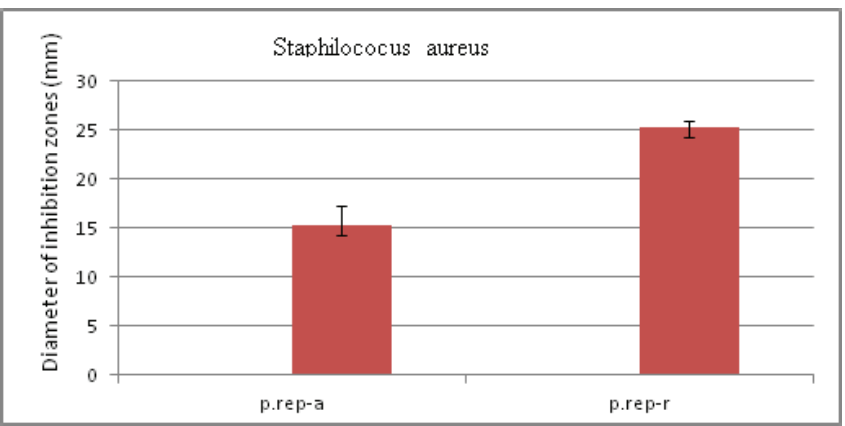

Fig. 1. The difference in activity of extracts of P. reptans aerial parts and rhizome against Staphilococus aureus $\mathrm{p}>0,05$

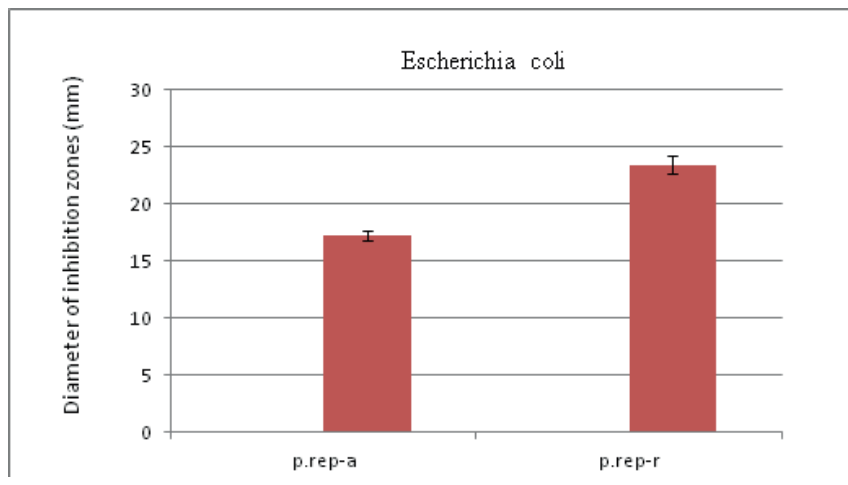

Fig. 2. The difference in activity of extracts of P. reptans aerial parts and rhizome against Escherichia coli p > 0,05

can be explained by the presence of tannin catechin in large quantities in the rhizome and probably its higher extraction with alcoholic solvents which were used in other study.

Methanol extract of $P$. recta applied at the concentration of $10 \mathrm{mg} / \mathrm{ml}$ caused the inhibition zone $(15 \mathrm{~mm})$ against $S$. aureus (10). In this study, aqueous extracts of $P$. reptans rhizome at the concentration of $10 \mathrm{mg} / \mathrm{ml}$ also induced the inhibition zone against this bacteria $(22 \mathrm{~mm})$, while the aerial part extract at this concentration did not show a significant activity against $S$. aureus and it showed the inhibition zone of $16 \mathrm{~mm}$ at the concentration of 50 $\mathrm{mg} / \mathrm{ml}$. The inhibition zones after application of $10 \mathrm{mg} / \mathrm{ml}$ of $P$. reptans aerial part and rhizome extracts against $E$. coli were $15 \mathrm{~mm}$ and $19 \mathrm{~mm}$. These values were significantly larger than the results obtained after application of $10 \mathrm{mg} /$ $\mathrm{ml} P$. recta extract $(12 \mathrm{~mm})(10)$.

Aerial parts of nine Potentilla species (P. argentea, $P$. fruticosa, $P$. recta, $P$. rupestris, $P$. erecta, $P$. anserina, $P$. nepalensis, $P$. thuringiaca, P.grandiflora) showed moderate effect against gram-positive bacteria (Staphylococcus aureus, Bacillus suptilis) at minimum inhibitory concentration of 12,5-100 mg/ $\mathrm{ml}$, while these extracts did not have any effect against gramnegative bacteria (Escherichia coli, Pseudomonas aeruginosa, Klebsiella pneumoniae). Moderate antifungal effect against Candida albicans was indicated (11). In our study, the rhizome showed moderate effect against Candida albicans but $P$. reptans aerial part did not show any effect.

Catechin is a dominant flavonoid from $P$. reptans rhizome and it may be assumed that it is the main carrier of the extract 
activity $(5,12)$. The activity of tannins in the plants of Potentilla genus against gram-positive, gram-negative bacteria and fungi was studied before when antibacterial and antifungal activity was observed (13). The study performed on three sorts of triticum showed that catechin and its derivates were synthetised in larger quantities within infectious plants rather than healthy ones, and the level of catechin also decreased after the infection ended, so it was considered that the synthesis of catechin was a defence response against pathogen attack (14). As for antimicrobial activity, it was proved that catechin had antimicrobial activity but the mechanism of action has not been explained yet. There is a conjecture that hydroxyl group of catechine molecule as a result of dehydrogenation gets replaced with carboxyl group which can bond with phospolipids within cell membrane, what can induce damages of membrane and physiological functions (15). Microbiological effect of aqueous extracts of $P$. reptans can be induced not only by catechin but larger number of secondary metabolites of different chemical structures which are present in extracts at the same time (16).

Large number of Potentilla species showed moderate effect not only against gram-positive bacteria but also against fungus $C$. albicans while there was not any effect against gram-negative bacteria or the effect was very weak (11). Although it was showed that Potentilla plants had moderate antifungal activity, for example tested Potentilla species had MIC range of $25-100 \mathrm{mg} / \mathrm{ml}$ against Candida albicans (7), while $P$. recta at concentration of $10 \mathrm{mg} / \mathrm{ml}$ induced the inhibition zone of $21 \mathrm{~mm}$, in our study none of the extracts at this concentration showed clear inhibition zone. Only at concentrations higher than $100 \mathrm{mg} / \mathrm{ml}$ the rhizome extract showed the inhibition zone of $16 \mathrm{~mm}$.

Antimicrobial activity of aqueous extracts of $P$. reptans aerial part and rhizome showed antimicrobial properties at concentrations of 10 to $150 \mathrm{mg} / \mathrm{ml}$. Aqueous extract of $P$. reptans rhizome at concentrations of 100 to $150 \mathrm{mg} /$ $\mathrm{ml}$ showed antifungal activity against $C$. albicans while the aerial part did not show any effect against this fungus. There was a significant difference in the activity of aerial part and rhizome extract against both bacterial strains. The rhizome showed statistically significantly stronger antimicrobial activity against examined bacterial strains than aerial part extract.

The results are in accordance with the results of other Potentilla species of this genus, as well as with the results of this species, significantly weaker though. Such weak results can be justified by the method of extract preparation. Obtained results confirmed the use of this plant in traditional medicine for the treatment of diarrhea and other conditions caused by various bacterial strains.

\section{ACKNOWLEDGMENT}

The authors would like to express gratitude to the Faculty of Medical Sciences, University of Kragujevac for Grant No. JP 28/10

\section{REFERENCES}

1. Tomczyk M, Latté KP. Potentilla-A review of its phytochemical and pharmacological profile. J Ethnopharmacol 2009;122 (2-18):184-204.

2. Gajic M, Josifovic M. Flora Srbije. Beograd: SANU; 1972.

3. Avci G, Kupeli E, Eryavuz A, et al. Antihypercholesterolaemic and antioxidant activity assessment of some plants used as remedy in Turkish folk medicine. J Ethnopharmacol 2006;107:418-23.

4. Gurbuz I, Ozkan AM, Yesilada E, Kutsal O. Anti-ulcerogenic activity of some plants used in folk medicine of Pinarbasi (Kayseri, Turkey). J Ethnopharmacol 2005; 101:313-8.

5. Marina T, Snezana C, Marija PM, et al. Antioxidant and Anti-Inflammatory activity of Potentilla reptans L. Acta Poloniae Pharmaceutica - Drug Research 2015;72(1):137-45.

6. Frances W, Barbara P, Alberto SM, Olivia C. Antimicrobial assays of three native British plants used in AngloSaxon medicine for wound healing formulations in 10th century England. J Ethnopharmacol 2012;144:408-15.

7. Tomczyk M, Leszczyńska K, Jakoniuk P. Antimicrobial activity of Potentilla species. Fitoterapia 2008;79:592-4.

8. Cheruiyot KR, Olila D, Kateregga J. In-vitro antibacterial activity of selected medicinal plants from Longisa region of Bomet district, Kenya. African Health Sciences 2009;9:S42-6.

9. Azmir J, Zaidul M, Rahman M, et al. Techniques for extraction of bioactive compounds from plant materials: A review. J Food Eng 2013;117(4):426-36.

10. Tosun A, Bahadir Ö, Altanlar N. Antimicrobial activity of some plants used in folk medicine in Turkey. Turk J Pharm Sci 2006;3(3):167-76.

11. Tomczyk M, Leszczyn' ska K, Tomczykowa M, Jakoniuk P. Screening of antimicrobial activity of aqueous extracts of the selected Potentilla L. species. Planta Med 2007;73: 854-5.

12. Saito H, Tamura M, Imai K. Catechin inhibits Candida albicans dimorphism by disrupting Cek1 phosphorylation and cAMP synthesis. Microb Pathog 2013;56:16-20.

13. Kołodziej H, Kayser O, Latte KP, Ferreira D. Evaluation of the antimicrobial potency of tannins and related compounds using the microdilution broth method. Planta Med 1999;65:444-6.

14. Ghassempour A, Mollayi S, Farzaneh M, et al. Variation of Catechin, epicatechin and their enantiomers concentrations before and after wheat cultivar-Puccinia triticina infection. Food Chem 2011;125:1287-90.

15. Chunmeia D, Jiabob W, Weijuna K, et al. Investigation of anti-microbial activity of catechin on Escherichia coli growth by microcalorimetry. Environ Toxicol Pharmacol 2010;30:284-8.

16. Cowan MM. Plant products as antimicrobial agents. Clin Microbiol Rev 1999;12:564-82. 